\title{
STRATEGI MENINGKATKAN DAYA SAING UMKM PIA ASMA' BERBASIS IPTEK DI DESA BERBEK KECAMATAN WARU SIDOARJO
}

\author{
Tommy Minggus ${ }^{1}$ \\ Muhammad Khusni Mubarrok² \\ Mahasiswa Fakultas Ekonomi dan Bisnis, Jurusan Manajemen Universitas Narotama \\ minggus.tommy@gmail.com ${ }^{1}$ \\ mubarrokkhusni@gmail.com²
}

\begin{abstract}
The purpose of this study is to determine the strategic decision making in improving the competitiveness of SMEs in the field of snack food production based on science and technology. The research method used in this study is a qualitative method. The results of the research are based on a SWOT analysis in overcoming problems faced by Pia Asma 'MSMEs in Berbek Village, Sidoarjo in order to increase competitiveness, then an alternative competitiveness strategy is by improving existing marketing systems, namely by registering their businesses in the online market so they can provide value added products and increase selling prices.
\end{abstract}

Keywords : MSMEs, science and technology, competitiveness

\begin{abstract}
ABSTRAK
Tujuan penelitian ini untuk menentukan pengambilan keputusan strategi dalam meningkatkan daya saing UMKM dibidang produksi makanan ringan dengan berbasis IPTEK. Metode penelitian yang digunakan pada studi ini adalah metode kualitatif. Hasil penelitian berdasarkan analisis SWOT dalam mengatasi permasalahan yang dihadapi oleh UMKM Pia Asma' di Desa Berbek, Sidoarjo agar dapat meningkatkan daya saing, maka alternatif strategi daya saing yaitu dengan cara memperbaiki sistem pemasaran yang ada, yaitu dengan mendaftarkan usahanya di pasar online sehingga dapat memberi nilai tambah produk dan meningkatkan harga jual.
\end{abstract}

Kata Kunci : UMKM, IPTEK, daya saing

\section{PENDAHULUAN}

Desa Berbek masuk dalam wilayah kecamatan Waru, meski wilayahnya lebih dekat dengan Surabaya Selatan namun wilayah ini tetap masuk dalam kabupaten Sidoarjo. letaknya yang lebih jauh dari kota Sidoarjo yang terkenal sebagai salah satu kota dengan jumlah UMKM terbesar di Jawa Timur. Bertata letak dipinggir kota Sidoarjo bukan berarti desa ini merupakan desa tertinggal. Justru ia memiliki daya tarik tersendiri karena letaknya yang sangat dekat dengan Surabaya. Lebih dekat ke Pusat Kota Surabaya 
dibanding harus berkendara ke Sidoarjo maka masyarakat sekitar lebih banyak mencari penghasilan di Surabaya, dan Melaksanakan kegiatan disekitar wilayah Surabaya.

UMKM Pia Asma' merupakan salah satu UMKM di Desa Berbek yang bergerak di bidang produksi makanan ringan. UMKM ini sudah berdiri kurang lebih 15 tahun sejak 2004. Awalnya Pia Asma' bukanlah sebuah UMKM, melainkan distributor kue kering. Salah satu pemiliknya yaitu Mas Umar setiap hari berkeliling ke banyak warung untuk menawarkan kue kering tersebut. Pada akhirnya, Mas Umar beserta istri berhasil membangun UMKM Pia Asma' dengan resep yang sudah cocok dengan lidah masyarakat. Kemampuan UMKM untuk dapat bertahan dan tumbuh tergantung dari faktor internal dan eksternal. Faktor internal seperti skala usaha, stakeholders personality, latar belakang pendidikan, dan budaya perusahaan (pelatihan internal), dapat mempengaruhi tingkat produktivitas dan inovasi UMKM. Sedangkan faktor eksternal yaitu faktor-faktor di luar perusahaan seperti akses terhadap permodalan dan lingkungan kebijakan, baik kebijakan pemerintah ataupun kondisi ekonomi suatu negara.

Permasalahan yang dialami oleh UMKM ini adalah kurangnya pengetahuan tentang IPTEK. Metode pemasaran yang dilakukan oleh pengusaha Pia Asma' selama ini yaitu dari mulut ke mulut. Pemanfaatan teknologi informasi mempunyai dampak positif terhadap strategi manajemen. Penggunaan teknologi informasi dapat menjadikan sebuah kekuatan dalam menentukan strategi serta dapat digunakan sebagai alat bagi organisasi bisnis dalam memberikan keuntungan pada aspek promosi dan kekuatan daya saing. teknologi informasi dapat memberikan keuntungan bagi dunia bisnis dalam mengurangi biaya serta meningkatkan kemampuan dunia usaha dalam melakukan koordinasi dengan pihak luar. Penting untuk usaha kecil dan menengah untuk melakukan inovatif dan menghasilkan produk dengan kualitas tinggi untuk berhasil dalam kompetisi global. Untuk dapat bersaing usaha kecil dituntut untuk menghasilkan produk yang memiliki ciri khas serta keuanikan dalam produk tersebut sehingga dapat diterima oleh pasar dan dapat bersaing dengan kompetitor.

\section{TINJAUAN PUSTAKA}

\section{Daya Saing}

Daya saing operasi merupakan fungsi operasi yang tidak saja berorientasi ke dalam (internal) tetapi juga keluar (eksternal), yakni merespon pasar sasaran usahanya 
dengan proaktif. (Muhardi, 2007). Kemampuan UMKM untuk dapat bertahan dan tumbuh tergantung dari faktor internal dan eksternal. Faktor internal seperti skala usaha, stakeholders personality, latar belakang pendidikan, dan budaya perusahaan (pelatihan internal), dapat mempengaruhi tingkat produktivitas dan inovasi UMKM. (Alimudin \& Yoga, 2018)

Dimensi daya saing suatu perusahaan adalah terdiri dari biaya (cost), kualitas (quality), waktu penyampaian (delivery), dan fleksibilitas (flexibility). (Muhardi, 2007).

\section{IPTEK}

Teknologi Informasi adalah suatu teknologi yang digunakan untuk mengolah data, termasuk memproses, mendapatkan, menyusun, menyimpan, memanipulasi data dalam berbagai cara untuk menghasilkan informasi yang berkualitas, yaitu informasi yang relevan, akurat dan tepat waktu, yang digunakan untuk keperluan pribadi, bisnis, dan pemerintahan dan merupakan informasi yang strategis untuk pengambilan keputusan. (Rahmana, 2009)

Teknologi Informasi (Informotion technology-IT) adalah yang memanfaatkan komputer sebagai perangkat utama untuk mengolah data menjadi informasi yang bermanfaat. (Fauzi, 2008).

\section{METODE PENELITIAN}

Metode penelitian yang digunakan pada studi ini adalah metode kualitatif. Metode kualitatif sebagai prosedur penelitian yang menghasilkan data deskriptif berupa kata-kata tertulis atau lisan dari orang-orang atau perilaku yang dapat diamati. (Moeleong, 2006). Dalam penelitian ini, objek penelitian adalah usaha kecil yang bergerak dibidang produksi makanan ringan (bakpia) di kawasan Desa Berbek, Sidoarjo. Teknik pengumpulan data adalah wawancara dan observasi. Jenis data yang digunakan adalah data primer, Menurut Hasan (2002 : 82) data primer ialah data yang diperoleh atau dikumpulkan langsung di lapangan oleh orang yang melakukan penelitian atau yang bersangkutan yang memerlukannya. Data primer di dapat dari sumber informan yaitu individu atau perseorangan seperti hasil wawancara yang dilakukan oleh peneliti. Data primer ini antara lain;

- Catatan hasil wawancara.

- Hasil observasi lapangan. 
- Data-data mengenai informan.

Teknik analisis data kualitatif adalah upaya yang dilakukan dengan jalan bekerja dengan data, mengorganisir data, memilah-milahnya menjadikan satuan yang dapat dikelola, mensistensikannya, mencari dan menemukan pola, menentukan apa yang penting dan apa yang dipelajari, dan memutuskan apa yang dapat diceritakan kepada orang lain. (Moeleong, 2006). Teknik pengumpulan data yang digunakan adalah wawancara dan observasi.Alat analisis yang digunakan adalah Analisis SWOT yang dirumuskan bedasarkan wawancara dan observasi. Adapun masalah yang akan diteliti di UMKM ini antara lain : Dorongan untuk meningkatkan daya saing dengan memanfaatkan IPTEK.

\section{HASIL DAN PEMBAHASAN}

\section{Nilai Positif Penerapan IPTEK Dalam Meningkatkan Daya Saing}

UMKM Pia Asma' merupakan salah satu jenis usaha yang mengedepankan cita rasa sebagai prioritas utama terhadap pelanggan. Pembahasan terkait IPTEK sangat membantu UMKM ini dalam meningkatkan daya saing terhadap para kompetitor dibidang usaha yang sama.

Analisis SWOT digunakan untuk menentukan medan kekuatan kompetitor maupun pendiri usaha UMKM Pia Asma' untuk mencapai tujuan yaitu meraih kesuksesan, kita perlu untuk mengetahui SWOT diri kita dan juga lawan. Dengan membandingkan kekuatan dan kelemahan diri sendiri dengan lawan kita dapat mengetahui kelemahan kita, apa yang mereka miliki tetapi tidak kita miliki, dengan begitu kita dapat mencari solusi untuk meminimalkan kelemahan kita, serta kita dapat memadukan kekuatan yang kita miliki dengan peluang yang ada (dengan kelemahan yang dimiliki oleh lawan) kita dapat menyusun taktik dan berbagai alternative strategi untuk menghadapi ancaman yang mungkin terjadi.

Selain itu analisis SWOT juga dapat digunakan. Dengan melakukan analisis ini kita dapat mengetahui kekuatan kita serta bagaimana meningkatkannya, kita dapat mengetahui kelemahan kita, juga dapat melihat peluang serta ancaman dari luar, dengan begitu kita dapat mencari solusi untuk menghadapi ancaman tersebut. Setelah melakukan 
analisis kita dapat mengetahui situasi dan kondisi yang sedang atau mungkin akan dihadapi. Analisis yang diterapkan dengan baik dapat membantu kita untuk mencapai tujuan secara efisien dan efektif.

\section{SIMPULAN DAN SARAN}

Berdasarkan masalah yang ada pada UMKM Pia Asma', yaitu kurangnya ilmu pengetahuan tentang teknologi. UMKM Pia Asma' bertekad untuk melakukan perubahan dengan memperbaiki sistem pemasaran yang ada, yaitu dengan berbasis online. Dengan cara, mendaftarkan usahanya di pasar online. Melakukan inovasi produk dan pasar perlu dilakukan untuk meningkatkan daya saing.

Untuk mengatasi permasalahan yang dihadapi oleh UMKM Pia Asma' di Desa Berbek, Sidoarjo agar dapat meningkatkan daya saing, maka alternatif strategi daya saing yaitu dengan cara memperbaiki sistem pemasaran yang ada, yaitu dengan mendaftarkan usahanya di pasar online sehingga dapat memberi nilai tambah produk dan meningkatkan harga jual.

\section{DAFTAR PUSTAKA}

Alimudin, A., \& Yoga, H. (2015). Strategi Meningkatkan Loyalitas Pelanggan Pada Usaha Kecil Produk Makanan Ringan di Surabaya. Sustainable Competitive Advantage (SCA), 5(1).

Alimudin, A., \& Yoga, H. (2018). Strategi Peningkatan Daya Saing Usaha Mikro Tempe Nasabah Lembaga Keuangan Mikro. EQUILIBRIUM : Jurnal Ilmiah Ekonomi dan Pembelajarannya, 6(1), 48-60.

Fauzi, A. (2008). Pengantar Teknologi Informasi. Yogyakarta: Graha Ilmu.

Hasan. (2002). Pokok-pokok Materi Metodologi Penelitian dan Aplikasinya. Bogor: Ghalia Indonesia.

Moeleong, L. J. (2006). Metodologi Penelitian Kualitatif . Bandung : PT Remaja Rosdakarya.

Muhardi. (2007). Strategi Operasi: Untuk Keunggulan Bersaing. Yogyakarta: Graha Ilmu. 
Rahmana, A. (2009). Peranan Teknologi Informasi Dalam Peningkatan Daya. Jurnal teknik Industri Universitas Widyatama.Vol.1. B11-B15. 